\title{
Coping with Violence and Extremism at International Level and Position of Islamic Republic of Iran
}

\author{
Seyyed Moosa Kazemi Naeini ${ }^{1}$, Dr. Hussein Alekajbaf ${ }^{2} \&$ Dr. Bahareh Heydari ${ }^{2}$ \\ ${ }^{1}$ Student in International Law, Faculty of Law, Payam Noor University, Tehran Iran \\ ${ }^{2}$ Associate Professor, Faculty of Law, Payam Noor University, Tehran Iran \\ Correspondence: Seyyed Moosa Kazemi Naeini, Student in International Law, Faculty of Law, Payam Noor \\ University, 3697-19395, Tehran Iran. E-mail: kazeminaeini@yahoo.com
}

$\begin{array}{lrr}\text { Received: June 5, } 2017 & \text { Accepted: July 1, } 2017 & \text { Online Published: August 30, } 2017 \\ \text { doi:10.5539/jpl.v10n4p165 } & \text { URL: https://doi.org/10.5539/jpl.v10n4p165 }\end{array}$

\begin{abstract}
Literature ruling current documents in resolutions of the UN in coping with violence and extremism is based on the "Action" after violence. Although the UN has considered the issue "Fundamental Prevention" in case of extremism and violence over recent years, it seems that there is not any agreement on it among the UN members, in particular permanent members of the Security Council. Resolution against Violence and Extremism, which was submitted to General Assembly, emphasizes on initial prevention from violence and extremism criticizing use of force. According to this Resolution, if the reflected slogans are realized and if countries are adherent to law sovereignty in practice, it will be possible to cope with violence and extremism internationally. Otherwise, violence would change to extremism and "terrorism" gradually so that not only a country but also world community will be affected. Reliance of countries just on Security Council regardless of regional mechanisms against violence is a criticism against the UN. In this regard, regional organizations can better react to crises compared to trans-regional organizations in accordance with their knowledge about neighboring countries' governments and people. The results of this study show there are some potential capacities in some countries, in Particular Islamic Republic of Iran, to persuade pacifist countries to cope with violence and extremism.
\end{abstract}

Keywords: security council, general assembly, violence, extremism, world resolution against violence and extremism, violence prevention

\section{Introduction}

Violence and extremism have had various aspects over the history so that its domain has been expanded with expansion in community size. In the contemporary period, the occurrence of two world wars is a symbol of violence and brutality of so-called pacifist communities. In fact, it can be stated that violence and extremism became a global concern in the $20^{\text {th }}$ century. In other words, violence changed from a technology deviation at that time to a further militarism so that technology, which was a solution for human to get rid of diseases and disasters, became itself a problem and threat for human life. The advent of colonialism and its relevant issues was another matter that paved the way for violence and extremism.

The UN, as an organization with public jurisdiction at the international scene, had approved various resolutions and declarations against violence and extremism. However, adoption of the resolution is not enough to condemn violence and extremism even if it is a general consensus in the General Assembly or Security Council; hence, it is necessary for governments to accept and apply these resolutions in practice. Seemingly, the UN has not been successful in confronting with violence and extremism due to different approaches of powerful countries coping with violence committed in the international community and interpretable nature of violence in viewpoint of countries.

\section{Role of Security Council in Coping with Violence and Extremism}

Security Council is one of the most prominent bases of the UN also the effective center for international dispute settlement investigating any case related to international security and peace. According to UN Charter, the Security Council has broader authorities in the context of international dispute settlement compared to other pillars of the UN. The functional nature of Security Council allows it investigating any kind of international 
dispute $^{1}$ and making decisions about it. In this case, competent authorities for dispute submission to Security Council consist of member and non-member states of the UN, General Assembly, Secretary-General of the UN and Security Council. International peace and security is highly important for the UN and Security Council so that the term "peace" has been used 26 times in text of the UN Charter, peaceful friendly relationships 10 times, and international relationship 20 times (Mosazadeh \& Koohi, 2010, P. 5). Although Security Council is responsible for international peace and security based on the UN Charter, Council has not been definitely successful in this case. In this regard, some of critics of Security Council believe that structure of the collective security system in the UN considers Security Council and its permanent members as interpreters of the concept of "protection of international peace and security", "Responsible reference of determining threat against peace", "breach of the peace and acts of aggression", "protector and executor" of peace. Considering these broad authorities, the Security Council has made some decisions after cold water about cases that had been under the jurisdiction of member states. In these cases, interests of the permanent members of the Security Council, contrary to opinion of Secretary-General, has made member states to implement selective and opportunistic method leading to the reduced ethical power of organization and trust of nations (Shayegan, 2001, P. 2).

The Security Council of the UN has coped with violence and extremism, which is mentioned in frame of "threat to international peace and security", at two general levels of "prevention" and "action" (decision on punishment). Security Council investigates causes for violence and extremism through different methods emphasizing on its authorities based on UN Charter; in case of threat to international peace, the Security Council would make some decisions based on Chapters 6 and 7 of the UN Charter. The extant study examines actions of Security Council based on chapter 7 of the UN Charter.

\subsection{Security Council Actions against Violence and Extremism Based Chapter 7 of UN Charter (Criminology and Punishment of Perpetrators and Instigators of Violence and Extremism)}

Security Council can make recommendations to maintain and restore international peace and security based on Article 39. It should be noted that the Security Council can issue its recommendations based on Articles 36 and 37 of the Charter of the UN in framework of Chapter 6, but it should be mentioned that when the Security Council makes some recommendations on the legal basis of Article 39, it is an initial step and Security Council would apply its binding measurements if parties do not comply with recommendations in accordance with Articles 41 and $42^{2}$. In This case, it can be stated that guarantee for implementation of Charter of UN is decision of Security Council based on Chapter 7. In other words, not only is evaluated adherence of international organizations and governments (even so-called "self-contained" organizations) in accordance with chapter 7 of the Charter, but also entry to force legally international treaties out of the charter through decisions made by Security Council based on this chapter.

In the context of coping with violence and extremism, chapter 7 of the UN Charter has had the most applications over the history. Of regulations contained in this chapter, Articles 41 and 42 have a specific position, because these articles are more valid in field of the Security Council approach toward violence and extremism. "In the opinion of some lawyers, these two articles are the most underlying factors for degradation of "national sovereignty" of governments at the international scene so that this degradation has been accelerated after the cold war and elimination of political and legal passivity of Security Council"3.

Security Council approach to violence may be emerged in different aspects including "condemnation of violence", "sanctions against countries threatening international peace and security", "creating safe and no-fly zones ", "sending peacekeeping troops to conflict zones", and "establishing a criminal court to punish the perpetrators of crimes".

Security Council would act in a specific order to prevent from violence and extremism. These actions are as follows:

\footnotetext{
${ }^{1}$ Permanent Court of Justice has defined international dispute in Mavromatis Case, "disagreement on a legal issue or reality, a legal disagreement or conflict between interests of parties".

${ }^{2}$ First resolution of Security Council about Nuclear Program of Iran (Resolution No. 1696 dated on 31 June 2006) was the introduction to issuance of other resolutions of Security Council based on Chapter 7. In other words, non-implementation of resolution based on Chapter 6 is not equal to invalidity of chapter 6 resolutions, but is a general decision that may lead to decision in specific meaning in chapter 7 in case of non-implementation.

3 Antonia Chaye."On chapter vii $1 / 2$ of the un charter", Available at: .http://fletcher.tufts.edu/ /media/Fletcher/Microsites/Fila/PDFs/FILADiscussionPaperNo0111.pdf.p.4 (accessed on 9 April 2015).
} 


\subsubsection{Condemnation of Violent Actions}

Usually, the first measurement of the Security Council after a threat to international peace and security is "condemnation" of violent behaviors and restore the default situation. Condemnation of violence is done under some circumstances in which there has been violence without any situation for peaceful settlement. Condemnation of violent actions by the Security Council can be either seen in introduction of resolutions or in articles and the main text of resolutions.

The content of issued condemnations in resolutions encompasses a wide range of topics. However, Security Council not only has condemned violent actions, but also asked for observing human rights and humanitarian law immediately ${ }^{4}$. In fact, condemnation of violent actions by Security Council indicates similar viewpoint of 5 permanent members of this organ. It is clear that when Security Councils makes decision to investigate a case in framework of chapter 7 of the charter, in particular in Articles 41 and 42 would condemn that action in its first resolution in order to assess viewpoints of 5 permanent members in taking practical measures. In other words, the specified condemnation in text of resolutions shows the legal belief of the Security Council in illegal activity and threat to international peace and security by states and other international actors.

\subsubsection{Sanction}

"Kofi Annan" former UN Secretary-General has expressed that resorting to sanction as a solution is considered by many of lawyers as a distance between war and negotiation chosen by the Security Council ${ }^{5}$. Accordingly, UN Security Council would issue sanction if the other proposed methods were inefficient. Security Council has enacted a wide range of international sanctions at different scale against determined goals by it. These sanctions are imposed based on the specific conditions ruling the case, including "diplomatic sanctions", "trade and investment sanctions", "communicational sanctions", and other types on sanctions. From the establishment of the UN till now, the Security Council has enacted some sanctions 25 times based on Article 41. Not only the Security Council has used sanction a tool for collective security, but also asked some countries in some sanction related resolutions to issue sanctions considering by UN voluntary in addition to sanctions imposed by the Security Council.

In the context of coping with violence and extremism, the Security Council has issued various sanction resolutions in different historical periods. The goal of the Security Council on sanctions is making states or violators of human rights to correct their behaviors and be adherent to the objective contained in the Charter of UN (Lopez, 2010, P. 298). The Security Council issues purposeful sanctions based on predetermined goals in order to prevent from deteriorate conditions in which, human rights are threatened. In other words, Security Council tends to reduce violence purposefully selecting some solutions including sanctions against weapon trade, blockage of financial sources of governments and terrorist groups. Economic sanction against governments violating human rights such as sanctions against Somalia, Sierra Leone, the Democratic Republic of the Congo, Eritrea and Libya.

Resolution 1844 against Somalia is a sample of Security Council measurements in field of sanction due to breach of human rights and humanitarian law. According to paragraph 3 of resolution 1844, governments are asked to block all economic and financial source paths of groups involving in Somalia in order to reduce tensions in this country that its circumstances create a threat to regional security and peach also the international community. One of considerable points in this resolution is specific terminology in paragraph 4. According to the mentioned paragraph, in addition to re-condemnation of all violent actions in Somalia, "incitement to violence" is condemned declaring its concerns about all actions against peaceful political measurements in that country ${ }^{6}$. Accordingly, Security Council introduces incitement to violence equal to violent action. According to review over sanction resolutions of Security Council, it was concluded that sanction is employed as a tool to cope with violence in order to reduce it.

\subsubsection{Peacekeeping Measurements}

The UN Security Council has not mentioned peacekeeping measurements directly and explicitly in none of resolutions to support civilians before 1999 (Holt and Berkman, 2006, P.5). According to issued resolutions by the Security Council since 2000, UN Security Council considers itself responsible to protect human life in armed conflicts and civil strife to support civilians in international conflicts creating safe zones, protecting people and

\footnotetext{
${ }^{4}$ Article 1

${ }^{5}$ A/59/2005 (21 March 2005): In Larger Freedom: Towards Development, Security and Human Rights for All

${ }^{6}$ The considerable point here is that Security Council shows concern in clause 5 of this resolution about increased piracy and weapon trafficking and financing insurgent groups through sea that may neutralize weapon sanctions against Somalia.
} 
keeping them far from conflicting zones. The UN Security Council is involved actively in peacekeeping measurements after 1990s because: first, Council could have a positive and active approach in coping with various international cases after the end of the cold war and elimination of UN passiveness (Shayegan, 2001, P. 245); hence, Security Council reacted to any case threatening international peace and security. Second, end of the cold war led to creation of some concepts such as "self-determination" and "dependency from central state" in the international community. This issue led to violence in many parts of the world; hence peacekeeping measurements of the UN have been applied in this context (Holt and Berkman, 2006, P. 7). Security Council has had various activities in the field of keeping international peace and security so that not only has resorted to the solution of "peacekeeping" but also has changed in quality assigning missions and tasks to peacekeepers. In this regard, peacekeepers had various tasks over this period, including "negotiate to make agreement between conflicting parties", "implementation of the peace agreement in Angola", "delivery of humanitarian assistance in Bosnia and Herzegovina and Somalia", "preparation and implementation of elections in Cambodia" and "maintaining safe and stable environment for democracy restoration in Haiti. Sometimes, the Security Council has changed non-force and peaceful nature of peacekeeping measurements assigning this task to peacekeepers, while it harmed validity of peacekeeping operations (Shayegan, 2001, P. 247).

Although peacekeeping measurements of Security Council led to considerable successes, the fact is that the solution of "sending peacekeepers to critical regions" has no response regardless of reasons for the committed violence. In other words, emphasis on sending peacekeepers after violence occurrence is not the only case and Security Council, as the most powerful organ of the UN, should prevent from violence since majority of countries are not interested in peacekeeping measurements of the UN. From the perspective of "South Countries", the UN is an agent of powerful countries that undertake peacekeeping measurements in favor of those countries. This perspective has been strengthened referring to member states of "Peace Commission" preparing the field for failure of peacekeeping measurements. Finance for such programs is another problem for the Security Council in lack of public acceptance of peacekeeping measurements (Murphy, 2007, P. 13).

\subsubsection{Establishment of International Criminal Courts}

"Justice has not been pursued by another criminal court after establishment of international military tribunals of Nuremberg and Tokyo in 1945, 1946 and punishment of the great criminals of World War II by international community allied. Horrific outcomes of mass destruction, deportation of civilians and abuse of women and children led to the establishment of two international by the Security Council in 1993 and 1994, respectively, to prosecute perpetrators of humanitarian law in the former Yugoslavia and Rwanda" (Shayegan, 2001, P. 203).

The UN Security Council established international criminal courts to punish war criminals that are threats to international peace and security. Accordingly, the Security Council introduces establishment of these international criminal courts as a mean to put an end to breach of humanitarian rights through implementing law sovereignty. As it was mentioned, Security Council does not have exclusive jurisdiction to establish international criminal courts, while the other organ of the UN, General Assembly, has the authority to establish international criminal courts. The Security Council established criminal courts due to public pressure and political decisions made by its members that have been challenging for states.

The first action of the Security Council to establish an international criminal court was asking member states of the international community to submit legal reports and documents about breaches of humanitarian rights in crisis-stricken countries to the Security Council. Accordingly, Security Council gathers submitted information forming a group of experts in the framework of a commission. Mission of experts is to collect documents on dramatic breaches of humanitarian rights and submit them to the Security Council. Security Council has established two important criminal courts at international level exclusively. International Criminal Tribunal for Yugoslavia (ICTY) and International Criminal Tribunal for Rwanda (ICTR) are the mentioned courts. Although these courts are not permanent like the International Criminal Court, they have contributed to international procedure in cases of violators of humanitarian rights (Sarooshi, 2000, P. 19).

\subsubsection{Creating No-Fly Zone}

"The purpose of creating safe zones in international humanitarian rights is supporting innocent people who are not involved in war, either soldiers that are far from the war due to disease or injuries or civilians who are not involved in war. The purpose of creating safe zones and regions is to provide humanitarian helps such as providing food and medicine, medical care and safety for vulnerable individuals" (Shayegan, 2001, P. 134).

Security Council set no-fly zone in the north of Iraq for the first time in 1990s in order to support human groups that were at risk (Hurrell, 1999, P. 59). Creation of no-fly zone is based on chapter 7 of the UN Charter; although some authors assume that the history of creation of safe zone goes back to 1870 at the time of "Henry Dunant" 
(Mc Goldrick, 2004, P. 2), the specific concept of no-fly zone implemented in Iraq for first time 1990s.

U.S, Britain and France sent their military force on April, 1991 considering the tacit consent of the Security Council $^{7}$ to protect Kurds who had been displaced in the northern mountains of Iraq due to Saddam Hussein's invasion. "Humanitarian operations of allied and UN were done to protect the Kurds, while such immediate action was not done for Shias, a sign of discrimination between Iraqi people" (Shayegan, 2001, P. 139). Security Council set 6 no-fly regions in 1993 to protect Bosnian Muslims against ethnic cleansing by Serbs. Security Council assigned the task to the United Nations Assistance Mission for Rwanda (UNAMIR) to support Rwandan refugees against brutal attack of Tutsi on May 1994 in order to prevent from deterioration of internal circumstance of Rwanda creating "safe zone". Furthermore, the Security Council set safe zones in other war regions, while it was defeated such as safe zone in Srebrenica, Bosnia in 1995. This defeat, which led to mass destruction of 8372 Bosnian Muslims, made Security Council not to set another safe zone until 1999. After the civil war in Libya, 2011, Security Council started setting safe zones; although this subject led to China and Russia governments' concerns, it finally was accepted by permanent members of the Security Council ${ }^{8}$. Although the creation of non-fly zones by the Security Council is a measurement to prevent from the deteriorated conditions and occurrence of human disasters, its political application by powerful countries besides discriminative behavior toward human communities who need humanitarian aids made numerous criticisms against this tool. However, creation of safe zones is one of measurements of the Security Council to reduce violence in international and national conflicts.

\section{Role of UN General Assembly in Coping with Violence and Extremism}

Although UN General Assembly has limited power, it has an acceptable legitimacy among countries in public opinion. Veto right, interfering and illegitimate actions of some member states of Council in the domestic affairs of other countries are issues that is accepted by many of lawyers. Accordingly, "politicization" is one of the most underlying challenges and criticisms against Security Council fighting against violence and extremism. Non-member states of the Security Council, which are developing countries, chose General Assembly as authenticate reference in accordance with the defect of the Security Council in coping with violence and extremism. General Assembly has conducted some measurements that are reviewed herein.

\subsection{General Assembly Actions against Violence and Extremism}

Violence and extremism is a phenomenon that is addressed by UN General Assembly approving relevant declarations and resolutions. In fact, although General Assembly is not exclusively responsible to keep international peace and security- this is the task of the Security Council- this prominent organ of UN fights against violence and extremism through different ways including "participation in financing peacekeeping operations", "recommendation to Security Council", "facilitating the relationship between the organs of UN", and "assigning some missions to Secretary-General of UN". Actions of General Assembly of UN are not just confined to mentioned options. General Assembly holds some sessions gathering all heals of countries annually to prepare the field for intellectual interaction. For instance, one of valuable actions of General Assembly is holding a session of heads of member states and the issuance of "Millennium Declaration"". The assumption and demand of the Millennium Declaration is that member states of UN should participate internationally to achieve 6 fundamental values, including "Freedom", "Equality", "Solidarity", "Tolerance", "Respect for Nature" And "Shared Responsibility". This declaration was approved in session 55 of UN General Assembly inviting states to respect for international law asking them to de adherent to law, sovereignty at national and international levels and helping UN to achieve its goals ${ }^{10}$.

Actions of General Assembly of UN against violence and extremism can be classified to several important actions including:

\subsubsection{Issuance of Resolutions and Declarations}

Judge Alejandro Alvarez presented a dissenting opinion at the international court of justice, pointing to legal and binding power of resolutions and declarations of General Assembly of UN. Judge "Alvarez" believed, "although

\footnotetext{
${ }^{7}$ Bruno Simma and many other international lawyers such as "Brown Lee" believe that any executive action without explicit permission of Security Council would lead to challenges. Accordingly, tacit consent of Security Council is not legally enough for a executive action. For further studies refer o: Bruno simma.(1999)," NATO, the UN and the Use of Force: Legal aspects", European Journal of International Law,Vol.10,pp.1-22

${ }^{8}$ S/RES/1973(17 MARCH 2011)

${ }^{9} \mathrm{~A} / \mathrm{RES} / 55 / 2$ (6-8 September 2000)

${ }^{10}$ Ibid. para 9.
} 
resolutions and declarations of General Assembly have no binding power at this time, these resolutions can reflect public opinion and demand of majority of governments if obtain binding power so that condemnation of a violation of Assembly declaration can be more sever for a state compared to the violation of a convention" 11 .

Although this statement is an acceptable legal opinion, it is not an absolute opinion. In other words, resolutions and declarations of General Assembly are binding if they are in favor of international law or one of fundamental human rights so they cannot be violated ${ }^{12}$.

\subsubsection{Establishment of Institutions and Organs Monitoring Human Rights}

Another action of UN General Assembly in the context of coping with violence and extremism is the establishment of some organs to monitor implementation of human rights. It can be stated that General Assembly established these organs, because General Assembly knew the point that it is not possible to encourage countries respecting human rights only through the issuance of resolutions and declarations without making them legally responsible; hence the General assembly had to monitor activities and measurements of countries in practice. Accordingly, General Assembly has established some organs to monitor implementation of human rights and these organs are either established based on regulations of the Charter of UN or by international treaties.

\subsubsection{Supervision over Implementation of Regulations and Human Rights' Documents at International Level}

"General announcement" of the violator state of human rights is one of the methods applied by the UN General Assembly to implement human rights. According to this method, general announcement of the violator state is an introduction to investigation of the situation of that state in the future. In other words, this announcement would make the other organs of human rights and states, which are interested in such treaties, revise their international relationships with the violator state. The power of this method is so high that none of states are willing to be in such conditions.

\subsection{Resorting to "Diplomatic" and "Economic" Sanctions ${ }^{13}$}

Although the general announcement of violator state of human rights at international scene is the most common tool used by human rights organs, when a state violates human rights dramatically then other states use some tools such as "diplomatic sanction" or "economic sanction" to put pressure on the violator state. Severe sanctions, either economic or diplomatic, can put an end to the mutual relationships between states. If the international community punishes violator state, then exclusion or suspension of membership of violator state in some international organizations such as the UN is another solution to put pressure on that state. In addition to diplomatic sanctions, economic sanctions are also other tools using to put pressure on states that violate human rights. "These sanctions, which are applied by states collectively or individually, have several examples over the recent decades. For instance, U.S and EU states imposed sanction against Myanmar after receiving reports about human right violations in this country" ${ }^{\prime \prime}$.

\subsection{Recommendation to Security Council}

According to Article 11 of the UN Charter, the General Assembly may consider the general principles of cooperation in the maintenance of international peace and security, including the principles governing disarmament and the regulation of armaments, and may make recommendations with regard to such principles to the Members, to the Security Council, or to both. Accordingly, "the General Assembly may discuss any questions relating to the maintenance of international peace and security brought before it by any Member of the United Nations, or by the Security Council, or by a state which is not a Member of the United Nations in accordance with Article 35, paragraph 2, and, except as provided in Article 12, may make recommendations with regard to any such questions to the state or states concerned or to the Security Council or to both" 15 . Powers of General Assembly include "power to initiate studies and investigations" to discuss and issue a recommendation in the field of international peace and security. This power, which was granted to General Assembly based on the

\footnotetext{
${ }^{11}$ Reservations to the Convention on Genocide, Dissenting Opinion of M. Alvarez, (1951) I.C.J. Rep. 49, 52 General Assembly refer to:

-Peterson, M.J, (2006), The UN General Assembly, Routledge publication, USA

${ }^{13}$ Imposing economic and diplomatic sanctions is the common task of Security Council and General Assembly

${ }^{14} \mathrm{http}: / /$ www.treasury.gov/resource-center/sanctions/Programs/pages/burma.aspx (visited on 9 january 2015)

${ }^{15}$ Clause 2 Article 11 of UN
}

${ }^{12}$ For instance, "freedom of belief and religion", which was approved on 18 December, 2014 by General Assembly, reminded former resolutions of General Assembly in its introduction and cases related to freedom of religion and belief in Universal Declaration of Human Rights and Connections naming it as the following resolution of former one. In other words, General Assembly refers to former resolutions and declarations to emphasize on the common background of them with former resolutions. For further studies about legal aspects of resolutions of 
Charter ${ }^{16}$, would place the Assembly in a condition to do tasks contained in the Charter. General Assembly has established come committees and commissions related to the case in order to initiate such investigations. For example, General Assembly established a committee in 1946 to investigate the circumstances of Palestine, established an investigation committee in 1956 for Hungary and created the United Nations Working Group in 1958 in Lebanon ${ }^{17}$ to reduce risks and threats to international peace and security.

This opinion that there is a "competitive relation" between the Security Council and General Assembly to keep international peace and security does not seem be correct, but interaction between these two important organs of the UN is toward facilitating their activities to keep peace and security. General Assembly is responsible to give some recommendations to Security Council based on its interpretations threating international peace and security. Security Council is responsible to make binding decisions based on the Charter; however, the Security Council can ask General Assembly, with regard to clause 1 of Article 12 of the Charter, to give some recommendations about international peace and security. According to the procedure of the UN, the Security Council has no power to interfere and make decision in some conditions explained in clause 7 of Articles 2 that is usually interpreted by states narrowly; accordingly, General Assembly of UN can investigate domestic conditions of member states submitting relevant cases in which, broad violence in the states may threat international peace and security. Procedure of UN General Assembly shows that this main pillar and its relation with clause 7 of Article 2 has attracted acceptance of UN member states simply. For instance, in case of investigating the situation of Hungary in 1956, General Assembly did not accept the claim that human rights are within domestic competence of the states (clause 7 of Article 2) (Raju, 2003, P. 80).

\section{Position of Islamic Republic of Iran against Violence and Extremism at International Level}

Islamic Republic of Iran, which the slogan of "neither East nor West" is the most significant principle of its Constitution not only criticizes classification of countries, but also considers their dependencies and presence in the international scene as the legitimate demand. In this regard, Iran government has made a lot of efforts in favor of peace after the Islamic Revolution and it depends on the effective presence of Iran in international organizations. The Iran government has proposed several acceptable doctrines to the UN that have been considered by General Assembly and other organs of the UN. Two underlying actions of Iran in this field have been accepted in framework of "Resolution of Dialogue of Civilizations" and "Resolution of a World against Violence and Extremism".

\subsection{Resolution of a World aginst Violence and Extrimism (Wave)}

Resolution of A WORLD AGINST VIOLENCE AND EXTRIMISM (WAVE), which was designed by the Islamic Republic of Iran for the first time, is the last activity of General Assembly in field of violence and extremism. The content of this resolution was the agenda number 15 assessed in the $68^{\text {th }}$ session of the assembly and approved through the consensus without opposition of any country. This resolution consists of 28 clauses, including various subjects that each of them is capable of facing extremism. The issuance reason base of this resolution, as it is mentioned in clause 1 of the resolution, is requirements contained in the UN Charter and the Universal Declaration of Human Rights.

\subsection{Commitment of Countries to Respect for Fundamental Human Rights}

"Whereas disregard and contempt for human rights have resulted in barbarous acts which have outraged the conscience of mankind, and the advent of a world in which human beings shall enjoy freedom of speech and belief and freedom from fear and want has been proclaimed as the highest aspiration of the common people ${ }^{18,}$ has been considered by the United Nations. One of the major considerations in Resolution of a WORLD AGINST VIOLENCE AND EXTRIMISM is to encourage governments to support and implement regulations related to human rights, because clause 2 of this resolution and previous resolutions ${ }^{19}$ have concentrated on necessity of respect for "Cultural Rights" that are often considered by countries against western human rights measures. In this regard, clause 6 reminds commitment of state members of organizations, mentioning necessity of respect for human rights and immediately clause 7 warns about the consequences of lack of respect for fundamental freedoms. According to the mentioned clause of the resolution, member states are persuaded that war and armed conflicts might lead to fundamentalism, violent extremisms, failure in the promotion of human rights and fundamental freedoms. In this regard, "the first and most important responsibility of governments is

\footnotetext{
${ }^{16}$ Article 13

${ }^{17} \mathrm{http}: / / \mathrm{www} . u n . o r g /$ en/peacekeeping/missions/past/unogilmandate.html

${ }^{18}$ Preamble of Universal Declaration of Human Rights approved in 10 December 1948

${ }^{19}$ Ibid., Para, 8
} 
ensuring a life full of peace free from violence for citizens living in the country. The result of adherence to such responsibility would lead to peaceful coexistence of government with neighbors leading to international peace and security ${ }^{20,}$.

\subsection{Refrain from Threat or Use of Force in International Relations}

According to Clause 4 of Article 2 of the Charter, "All Members shall refrain in their international relations from the threat or use of force against the territorial integrity or political independence of any state, or in any other manner inconsistent with the Purposes of the United Nations". According to the explicit content of this Article, use of military force in international community is not accepted is it is not consistent with the Charter of United Nations and social security. "Use of force and formulation of use of coercive force in the international community is so ambiguous that is one of the most perplexing subjects for lawyers and international law" (Rosenne, Op.Cit: 109). In fact, this regulation is a complementary for Clause 3 of Article 2 in which, government are asked to "All Members shall settle their international disputes by peaceful means in such a manner that international peace and security, and justice, are not endangered". Despite the emphasis of Charter on non-use of force in international relations, we still see the force used by powerful countries. For instance, the campaign of USA against Iraq has been opposed to the UN Charter and Security Council Resolutions in the opinion of many of international lawyers ${ }^{21}$.

The purpose of this introduction was to study resolution of a World against Violence and Extremism and its emphasis on non-use of force. The resolution of a World against Violence and Extremism has highlighted the subject in its clause 3 that "state members shall not use force in international relations" and considers the outbreak of violence and armed conflicts between governments as a reason for promotion of violence and extremism ${ }^{22}$. "As it is mentioned by Iranian Agent in Organization General Assembly, if states just emphasize on issuance of a resolution in the UN to convict violent activities regardless of circumstances leading to such behaviors, we will fail to cope with violence and terrorism ${ }^{23}$ ".

\section{Conclusion}

It should be stated that Resolution of a world against violence and extremism emphasizes on the promotion of negotiation culture along with increased tolerance between states. Doctrine of Islamic Republic of Iran has supported non-use of force at international level. Although Iran is a leading country in terms of military power, capable of repelling any kind of threat, this country has never supported any power in international conflicts based on its international doctrine. The experience of imposed war indicated that lack of impartiality in armed conflicts may lead to increased violence. Accordingly, Islamic Republic of Iran has not supported involved groups in conflicts, considering arm embargo of parties. According to doctrine of the Islamic Republic of Iran that is embodied in resolution of a world against violence and extremism, Iran has a critical approach toward UN failure in prevention from violence. In general, Islamic Republic of Iran has a preventive approach toward violence and extremism. The main purpose of the project of a world against violence and extremism is emphasis on prevention from violence, providing the field for it in the framework of the mentioned resolution. Proposing the resolution of a world against violence and extremism reduced Iran-phobia considerably so that this was chosen as the topic for this paper. The purpose of this resolution, which was approved with consensus, was to show lack of attention of states and international institutes to the issue of violence prevention at international level. Late arrival of UN in reducing violence and the presence of some tools such as use of force, which lead to violence and extremism, are the issues considered in theory of this resolution. Unfortunately, politicized approach of states in sending a peacekeeping force by UN can be seen; hence, Islamic Republic of Iran has been always opposing to selective behavior coping with international crises.

\section{References}

Bruno, S. (1999). NATO, the UN and the Use of Force: Legal aspects. European Journal of International Law, (10).

\footnotetext{
${ }^{20}$ Ibid., Para, 8

${ }^{21}$ This attitude is so strengthened in view of some lawyers that they express, "when government justify an attack to a country in terms of political aspect, that country will not pay attention to international law and its international commitment". To see criticisms against Iraq War refer to: Mc Goldrick, Dominic,(2004),From 9-11 To The Iraq War 2003; The International Law in an age of Complexity, Hart Publication , UK,p.35

${ }^{22}$ According to clause 3 of this resolution, deplores attacks on religious places and shrines and cultural sites in violation of international law, in particular human rights and humanitarian law, including any deliberate destruction of relics and monuments.

${ }^{23}$ General Assembly Resolution/A.60/PV.99
} 
Holt, V. K., \& Berkman, T. C. (2006). The Impossible Mandate? Military Preparedness, The Responsibility To Protect And Modern Peace Operations. The Henry L. Stimson Center publication.

Lopez-Jacoiste, E. (2010). The UN Collective Security System and its Relationship with Economic Sanction and Human Rights, Max Planck Yearbook of United Nations Law, Vol. 14.

Mc Goldrick, D. (2004). From 9-11 To the Iraq War 2003. The International Law in an age of Complexity, Hart Publication, UK.

Mosazadeh, R., \& Koohi, I. (2010). Rights of international organizations, the rights of the Security Council, Tehran, publiMizan Pub., first edition.

Murphy, J. (2007). International perspectives and initiatives. Volume 24, Issue 1, March 2007, Pages 62-68.

Peterson, M. J. (2006). The UN General Assembly, Routledge publication, USA.

Raju G. C. T. (2003). Yugoslavia unraveled: sovereignty, self-determination, intervention, Lexington Books, UK.

Sarooshi Dan. (2000). The United Nations and the Development of Collective Security: The Delegation by the UN Security Council of its Chapter VII Powers. Retrieved from https://global.oup.com/academic/product/the-united-nations-and-the-development-of-collective-security-97 80198299349 ?cc $=$ us\&lang $=$ en\&\#

Shayegan, F. (2001). The UN Security Council and the concept of international peace and security, under supervision of Jamshid Momtaz, Tehran, Faculty of Law and Political Science, First Edition.

\section{Copyrights}

Copyright for this article is retained by the author(s), with first publication rights granted to the journal.

This is an open-access article distributed under the terms and conditions of the Creative Commons Attribution license (http://creativecommons.org/licenses/by/4.0/). 